\title{
Os desafios da economia solidária
}

\section{Pedro Hespanha et Rui Namorado}

\section{(2) OpenEdition}

\section{Journals}

Édition électronique

URL : http://journals.openedition.org/rccs/536

DOI : $10.4000 /$ rccs.536

ISSN : 2182-7435

\section{Éditeur}

Centro de Estudos Sociais da Universidade de Coimbra

\section{Édition imprimée}

Date de publication : 1 mars 2009

Pagination : 3-5

ISSN : 0254-1106

\section{Référence électronique}

Pedro Hespanha et Rui Namorado, "Os desafios da economia solidária », Revista Crítica de Ciências Sociais [En ligne], 84 | 2009, mis en ligne le 01 décembre 2012, consulté le 22 septembre 2020. URL : http://journals.openedition.org/rccs/536 ; DOI : https://doi.org/10.4000/rccs.536 


\section{Os desafios da economia solidária}

Necessidades sociais de natureza mais elementar, tais como o emprego, os consumos básicos ou a segurança social, voltaram a tornar-se preocupação quotidiana de milhões e milhões de cidadãos de todo mundo, incluindo os daqueles países que se dotaram de sistemas de protecção mais avançados.

A falência dos sistemas de protecção - desde os mais eficientes aos mais rudimentares, associada às mutações do capitalismo nesta fase de intensa globalização e às reformas dos sistemas de protecção social dos Estados nacionais - deu lugar ao aparecimento de novas formas de organização da sociedade civil para dar resposta a essas necessidades. Neste processo, as antigas formas organizativas, tais como as cooperativas, têm sido o suporte da experimentação de novas práticas e novas configurações jurídicas, muitas vezes difíceis de classificar devido ao seu bibridismo, mas sempre sujeitas ao mesmo princípio da solidariedade.

Solidariedade é, assim, um dos atributos que cientistas sociais associam a estas dinâmicas emergentes e economia solidária é uma expressão que se está a afirmar em muito lado para designar estas formas - velhas ou novas - de satisfazer as necessidades económicas e de existência sem passar pelo mercado ou pela sua lógica competitiva.

Porém, e sem entrar em detalhes sobre o conceito, tem de se reconhecer que a designação de Economia Solidária está ainda pouco difundida entre os portugueses e ainda soa estranha para muitos. Paradoxalmente, a economia solidária, em Portugal, parece estar a sofrer um processo rápido de institucionalização mesmo antes de se ter constituído como uma realidade pujante. $\mathrm{Na}$ verdade, ela já entrou no discurso de alguns agentes políticos e é usada a torto e a direito por eles como uma fórmula mágica que estimula as populações mais marginalizadas a resolverem os seus próprios problemas.

$E$, estando ainda em curso o amadurecimento desse conceito, compreende-se que alguns o identifiquem com a economia social, tal como esta é entendida na Europa, nomeadamente, pelas instâncias da União Europeia. No mesmo sentido, no caso português, a economia solidária pode ser encarada como correspondendo, no essencial, ao "sector cooperativo e social", previsto na Constituição como distinto, quer do sector público, quer do sector privado. 
Referir aqui o paradoxo da apropriação ou institucionalização da economia solidária em Portugal serve apenas para fazer sobressair os riscos que existem de degeneração do conceito. Tratando-se de uma designação ampla, com entendimentos eventualmente diferenciados em função dos contextos nacionais, o conceito de economia solidária presta-se bem a uma análise comparativa pelo facto de centrar a sua definição num atributo das relações sociais - a solidariedade - bem demarcável do padrão dominante dessas relações no campo económico.

Como algumas investigações levadas a cabo em países com diferentes graus de desenvolvimento económico demonstraram, os fenómenos de dinamismo e mobilização da sociedade civil assumem características distintas, fruto do seu enquadramento em realidades sociais e económicas diferenciadas. Contudo, a comparação das experiências ocorridas em contextos diferentes é muito rica. Ela ajuda a compreender, desde logo, o modo como as lógicas de cooperação solidária se podem plasmar em diferentes configurações práticas sem perder a sua força; depois, permite detectar como os mesmos factores globais podem desencadear respostas distintas de acordo com as especificidades nacionais; ainda, ajuda a compreender a importância que têm, no processo de desenvolvimento da economia solidária, factores como a cultura participativa da sociedade civil, o grau de autonomia desta face ao Estado ou o papel dos movimentos sociais na procura de soluções alternativas à economia baseada na competição.

Foi com estas preocupações que o CES organizou o seminário Desafios da economia solidária em Janeiro de 2008. O desafio consistia em abordar uma realidade nova, com contornos ainda não claramente delineados $e$ muito diversa na sua morfologia, que se apresentava como uma alternativa ao modelo dominante das práticas económicas e sociais de cunho individualista moldadas pelo capitalismo. Desafio era também a troca de conbecimento e de experiências práticas entre dois países - Portugal e Brasil - simultaneamente próximos - pela sua língua, matriz institucional e lugar intermédio no sistema mundial - e distantes, pela sua localização geográfica, diversidade cultural e beranças históricas.

Neste seminário a economia solidária foi escrutinada de diversos ângulos e perspectivas: de uma perspectiva teórico-epistemológica, discutindo questões como a do lugar dos saberes popular e militante na construção do objecto, a da construção conceptual e escolb a dos atributos, a do enquadramento analítico do fenómeno ou a das metodologias de estudo; de uma perspectiva socio-política, discutindo as condições de emergência dos empreendimentos solidários, os modos de articulação e auto-regulação do campo da economia solidária, o papel dos actores e promotores externos (sindicatos, partidos, ONGs, movimentos eclesiais, etc.), a condição de movimento social ou os 
efeitos do reconbecimento institucional; $e$, de uma perspectiva comparada, discutindo as experiências brasileira e portuguesa, os sucessos e as dificuldades da economia solidária nestes países, tendo em conta a sua diferente pertença a espaços ou organizações de âmbito supranacional.

O presente numero da Revista Crítica de Ciências Sociais vem agora trazer a público um conjunto de textos que fixaram as intervenções havidas no seminário e que reflectem as preocupações e as perspectivas acima enunciadas.

Pedro Hespanha

Rui Namorado 